\section{Compression in chronic edema; the orthopedic aspect for the venous system}

\section{Thomas Stumptner}

Specialist in Orthopaedics, Phlebology, Chirotherapy, Nürnberg, Germany

Venous edema is the extravasal volume overloading of the tissue of the whole leg. The subfascial edema is responsible for the symptoms by an increased tension of the fascia due to this volume overloading. It is starting point for further venous diseases. ${ }^{1,2}$ The edema either results from an insufficiency of the valves or a not sufficient working of the pumps. These both structures depend on the fascia. ${ }^{3-9}$

The fascia is a non-elastic structure with the architecture of a Chinese finger. It determines the tonus of the musculature. ${ }^{10,11}$ Due to the angles of the Chinese finger a diffe- rent tonus of the subfascial muscles results. Too big angles reduce the subfascial tonus (Figures 1 and 2).

The structure of the fascia depends on the posture. Only the right position of the foot guarantees the right tonus of the muscles. The footposition is depending neurologically on the afferences by the foot as the basal sensor of the body's coordination system. Mechanically it depends on the shoe. ${ }^{12}$ Every wrong footposition changes the structure of the fascia. So for example a high heel on the shoe will increase the angles of the fascia and will lead to a reduction of the muscle tonus and an insufficiency of the valves.

Simultaneously the reduced movement of the joint wearing a high heel reduces the work of the ankle pump ${ }^{12-16}$

By harmonizing the fascia the natural compression effect by the muscle tonus will be guaranteed. Nonelastic compression therapy imitates the fascia and enables a high muscle tonus during contraction of the muscle as its natural principle. ${ }^{2,12,17}$ Elastic com-
A

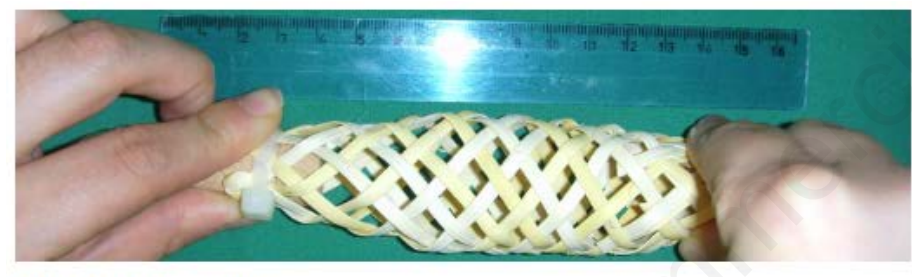

Größer $90 \mathrm{Grad}$ larger

B

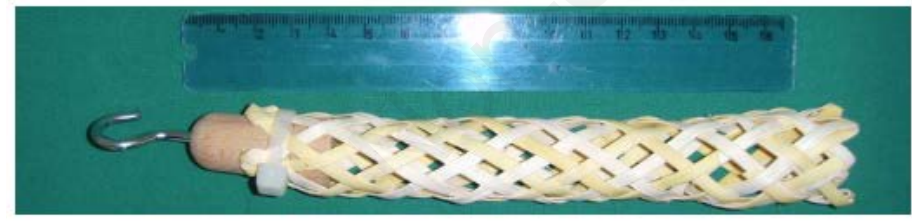

neutral

C

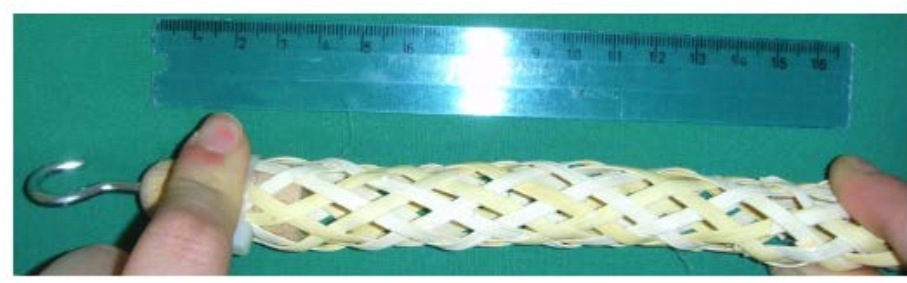

Kleiner 90 Grad smaller

Figure 1. Showing a mechanical model for the action of the fascia: A) by pushing the tubular model together (Chinese finger) the angles between the fibers will get larger, B) normal in the relaxed position, C) smaller when the model is streched.
Correspondence: Thomas Stumptner, Fürther Str. 244a (Auf AEG), 90429 Nürnberg, Germany.

Tel.: +911.23.75.470 - Fax: +911.23.75.471.

E-mail: info@dr-stumptner.de

Conference presentation: International Compression Club (ICC) Meeting, Rotterdam, 2018.

This work is licensed under a Creative Commons Attribution 4.0 License (by-nc 4.0).

(C) Copyright T. Stumptner, 2018

Licensee PAGEPress, Italy

Veins and Lymphatics 2018; 7:7994

doi:10.4081/vl.2018.7994

pression suppports this anatomical situation.

The orthopedic aspect, a equilibrated balance of posture and position is the condition for the sufficient working of the valves as well as for the pumps. It depends fundamentally on the foot. So considering the foot based on its sensory task as well as its mechanical job is an efficient starting point for venous therapy. By a weak insole it could receive the necessary afferent stimulation for a balanced position. Proper footware therefore plays a crucial role in treating venous problems. ${ }^{12}$

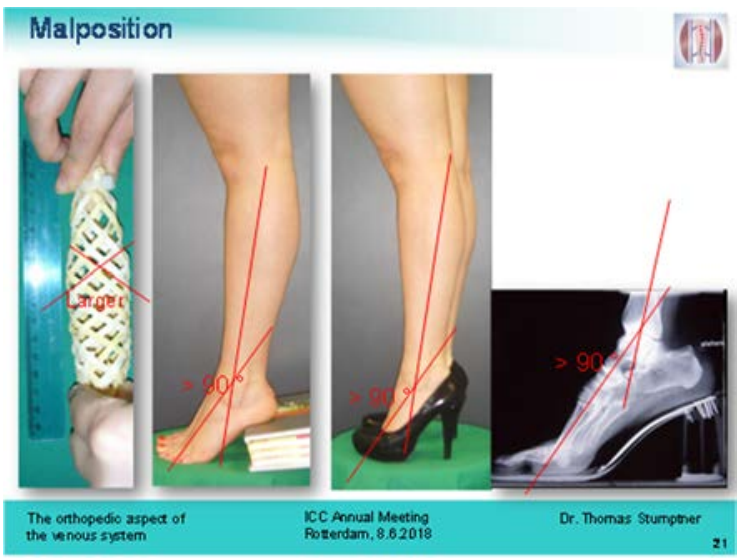

Figure 2. Demonstrating the effect of footposition on the calf: The muscle becomes pushed together passively by a heel. The angles of the fascia change. The tonus of the muscle reduces. An active contraction is no more possible. 


\section{References}

1. Stumptner T. Subfascial edema due to venous incompetence demonstrated by MRI. ICC annual meeting Amsterdam 2017. Available from: http://www. tagungsmanagement.org/comp/images/PDF/amsterdam2017_stumptner.pd $\mathrm{f}$

2. Stumptner T. Das subfasziale venöse Ödem im NMR. Objektivierung des zentralen Korrelates der phlebologischen Pathologie? Phlebologie 2018;4: 205-9.

3. Braune W. Die Oberschenkelvene in anatomischer und klinischer Beziehung. Leipzig: Veit; 1871.

4. Goerttler K. Über den Einbau der großen Venen des Unterschenkels. Z Anat 1953;116:591-609.

5. Kügelgen vA. Über den Wandbau der großen Venen. Morph Jb 1951;91:447.

6. Lanz vT, Kressner A, Schwendemann R. Der Einbau der oberflächlichen und der tiefen Venen am Bein, morpholo- gisch und konstruktiv betrachtet. Zeitschr Anat Entwicklungsgesch 1936; 108:695.

7. Lanz vT. Über den funktionellen Einbau peripherer Venen. Anat Anz 1936/37;83:51.

8. Schade H, Pich H. Die Pulsationsübertragung von der Arterie auf die Vene und ihre Bedeutung für den Blutkreislauf. Zschr Kreislauff 1936;28:131-72.

9. Schulze W. Über die anatomschen Bedingungen für die Metastasierung bei der Allgemeininfektion. Dtsch Z Chir 1933;239:34.

10. Askar O, Abou-El-Ainen M. The surgical anatomy of the deep fascia of the human leg. J Cardiovasc Surg 1963;4: 114-25.

11. Askar O. Plication of the deep fascia of the calf as a new line of treatment in certain cases of primary varicose veins of the lower limp. J Cardiovasc Surg 1961;2:222.

12. Stumptner T. Der Fuß in seiner neurofunktionellen und mechanischen
Bedeutung für den Beinvenenkreislauf. Orthopädieschuhtechnik 2007;12.

13. Kügler C, Strunk M, Rudofsky G. Bedeutung einer eingeschränkten Gelenkbeweglichkeit für den Blutabstrom aus gesunden Beinvenen. Phlebologie 1999;28.

14. Schmeller W, Schadwinkel M. Die Beinvenenhämodynamik Abhängigkeit vom Bewegungsausmaß im oberen Sprunggelenk. Phlebol U Proktol 1987;16.

15. Staubesand J. Die anatomischen Grundlagen der sog. Sprunggelenkpumpe (ankle pump). Swiss Med 1980;2, 4a:48-51.

16. Staubesand J, Heisterkamp T, Stege H. Über die Wirkung aktiver und passiver Bewegungen im oberen Sprunggelenk für den venösen Rückstrom. Phlebologie 1993;22:264-71.

17. Lippmann HI. The mechanical basis of supportive therapy in chronic venous insufficiency. Zentr Phlebologie 1970;9:77-86. 